\title{
GEOCHRONOLOGICAL AND STRUCTURAL INVESTIGATIONS OF THE NORTHERN PELAGONIAN CRYSTALLINE ZONE. CONSTRAINTS FROM K/AR AND ZIRCON AND APATITE FISSION TRACK DATING. T. MOST ${ }^{1}$, W. FRISCH ${ }^{1}$, I. DUNKL ${ }^{1}$, B. KADOSA ${ }^{2}$, B. BOEV ${ }^{3}$, A. AVGERINAS ${ }^{4}$, A. KILIAS ${ }^{4}$
}

\begin{abstract}
The northern part of the Pelagonian Zone experienced a polyphase deformation and metamorphism. Four groups of K/Ar biotite and white mica ages document (I) Hercynian emplacement of plutonic rocks, (II) Eohellenic nappe stacking associated with penetrative deformation / recrystallisation, (III) a Paleocene event in the Mesocoic cover rocks in Greece and (IV) a westward movement of West Pelagonian nappes during Eocene to Oligocene time. First zircon/apatite fission track ages clustering around $70 \mathrm{Ma}$ and 45 to $30 \mathrm{Ma}$.
\end{abstract}

KEY WORDS: Central Pelagonian Zone, West Pelagonian Zone, Hercynian orogeny, Alpine orogeny, Eohellenic nappe stacking, K/Ar chronology, fission track dating

\section{1.) GEOLOGIC SETTING AND FRAMEWORK}

The northern Pelagonian crystalline is part of NNW-SSE trending Pelagonian Zone which extends from Skopje to northern Evvia covering a ca. $420 \mathrm{~km}$ long and ca. $60 \mathrm{~km}$ wide area (Fig. 1A). The most part of the crystalline massif represents Mesocoic metaclastic and metacarbonatic sequence but also contains Hercynian relics (PAPANIKOLAOU et al., 1982; PAPANIKOLAOU \& STOJANOV, 1983).

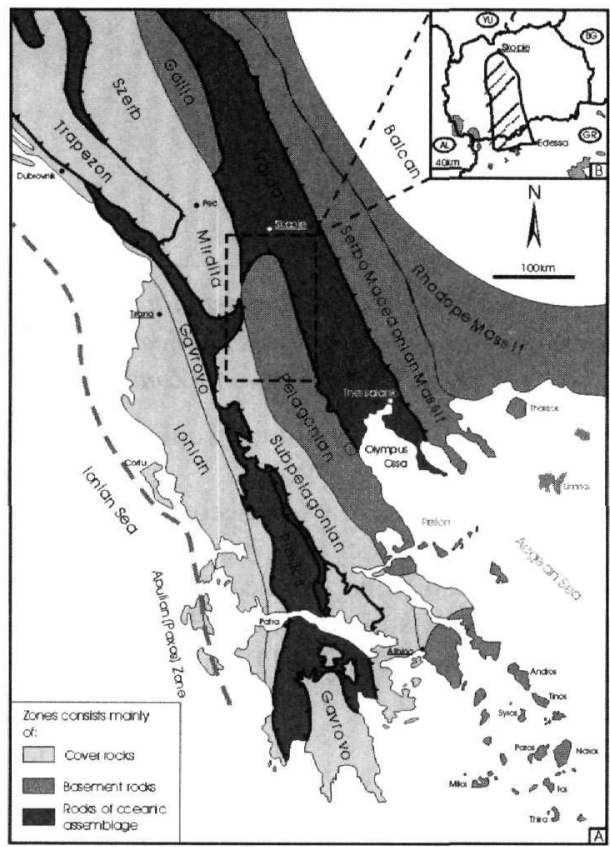

Fig. 1A: Geological sketch map of major tectonic units in the Dinaridic-Hellenidic realm compiled from AUBOUIN, 1973; 1B: Geographic position of the study area (hatched area)

1. Institute of Geology, University, D-72706 Tóbingen; email: thomas.most@uni-tuebingen.de

2. Institute of Nuclear Research, H-4026 Debrecen

3. Faculty of Mining and Geochemistry, University, MK-91000 Skopje

4. Institute of Geology, University, GR-54006 Thessaloniki 


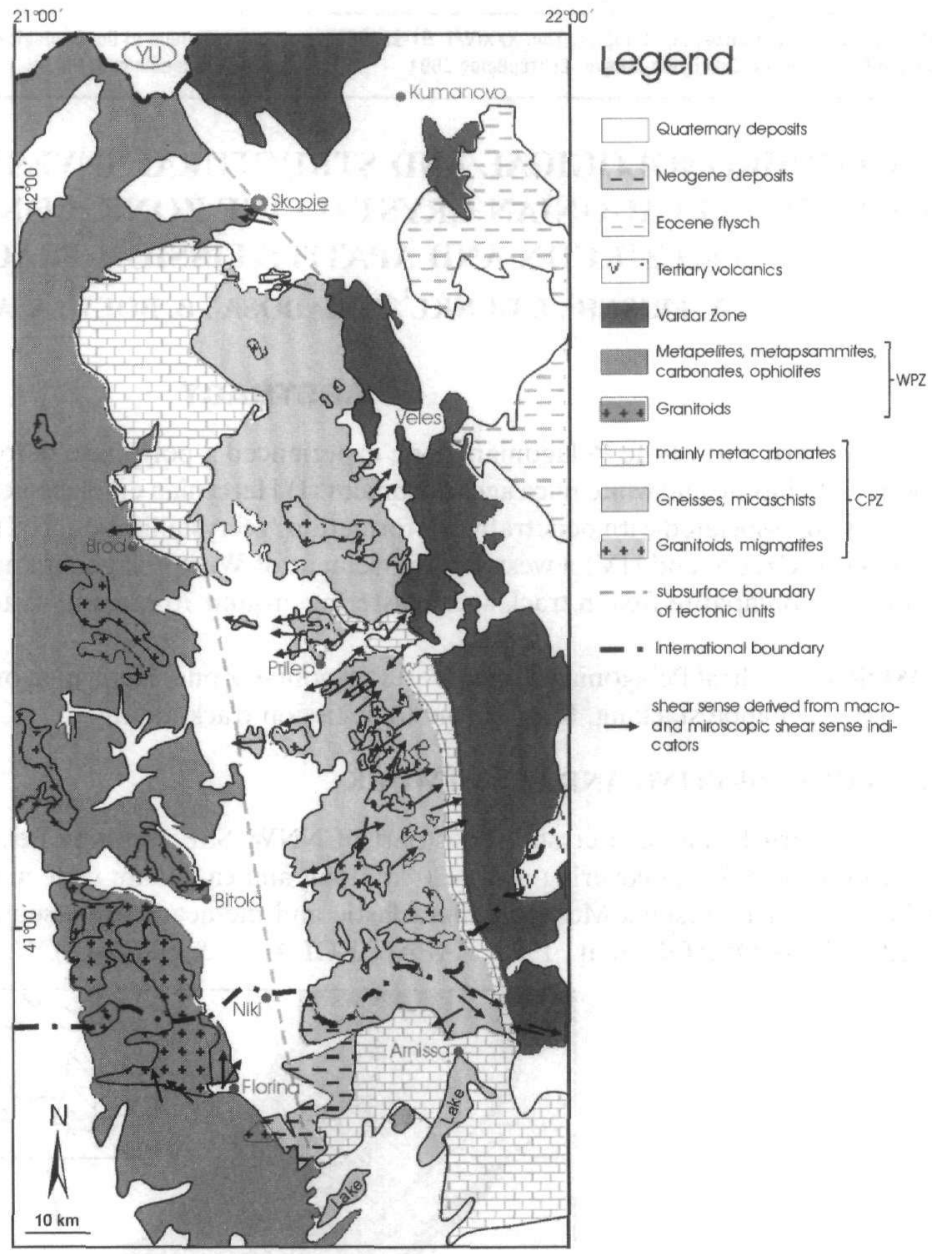

[Fig. 2: Simplified geological sketch map of the Pelagonian crystalline zone and adjacent units. Arrows indicate sense of shear derived from macro-/microscopic shear sense indicators. CPZ = Central Pelagonian Zone; WPZ $=$ West Pelagonian Zone $]$

Tectonic windows within the Pelagonian Zone are known from the Olympus area and from the south. The geographic position of the study area is shown in Fig. 1B.

For the southern part of the Pelagonian Zone Early Cretaceous nappe stacking a Tertiary extensional phase is proven by numerous authors (e.g., SCHERMER et al., 1990; WALCOTT, 1998; LIPS et al., 1998, 1999).

From the northern part of the Pelagonian Zone practically no modern structural geological, petrological and thermochronological data are available. First petrogenetic characteristics of the rocks and some structural data have been presented by KOSSMAT, 1924; MEDWENITSCH, 1956; JANCEV et al., 1977 and DUMURDZANOV, 1985. An unspecified K/Ar age of 800-1000 Ma for a Pelagonian granite had been presented by DELEON, 1966.

The aim of this paper is to present new $\mathrm{K} / \mathrm{Ar}-$, and preliminary zircon and apatite fission track data.

\section{2.) PETROLOGY}

Following the framework of KOSSMAT, 1924; MEDWENISTSCH, 1956; ARSOVSKI et al., 1977 and JANCEV, 1977 the Central Pelagonian Zone (CPZ, Fig.2) can be separated into two different units. The lower (central part) consists of gneisses, micaschists, granitoids, amphibolites and migmatites, while the upper part comprises a mixed series of micaschists, gneisses and marbles. The metamorphic gradient increases from greenschist facies $($ quartz + plagioclase + garnet + biotite + white mica + chlorite + epidote \pm actinolite \pm 


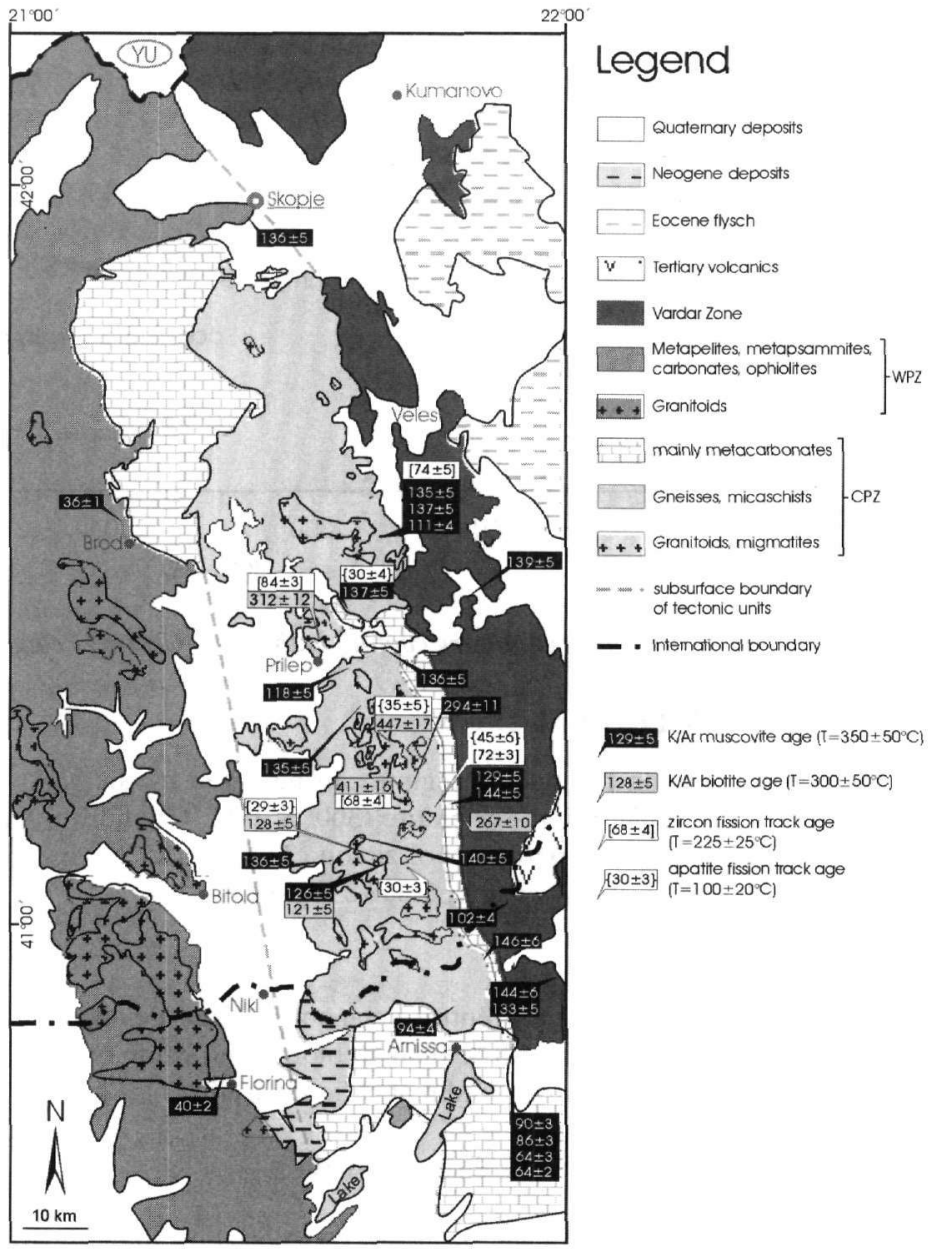

[Fig. 3: Distribution of K/Ar- biotite and white mica, zircon and apatite fission track ages; CPZ = Central Pelagonian Zone; $\mathrm{WPZ}=$ West Pelagonian Zone]

chloritoid) conditions at the margin of the Central Pelagonian crystalline to amphibolite facies (quartz + plagioclase + kyanite + staurolite + white mica + biotite) conditions in the central part. The high pressure / low temperature paragenesis of crossite + epidote + white mica + albite + quartz represents a metamorphic event under blueschist facies conditions at the northern margin of the Pelagonian Zone (Mt. Vodno near Skopje).

\section{3.) STRUCTURAL GEOLOGY}

First macro- and microscopic structural investigations document a polyphase deformation history of the Central Pelagonian Zone and the adjacent tectonic units of the Vardar- and West Pelagonian Zone.

Regarding to the current investigations in this paper only a brief summary of the tectonic features of the Central Pelagonian Zone is given below.

The dominating fabric element is a penetrative foliation affecting all metamorphosed Pelagonian rocks, whereas the granitoids are only deformed along their margins. The foliation is associated with isoclinal folding and dips slightly to eastern directions in the east and to western directions in the west, while the central part is characterised by both dip directions. Wide to open folds and a crenulation cleavage document a later phase. The latest, brittle deformation stage is represented by cataclastic shear zones and pseudotachylites.

Macro- and microscopic shear sense indicators show NE directed movement in the E and W-SW directed transport in the western part of the Central Pelagonian Zone (Fig. 2). 


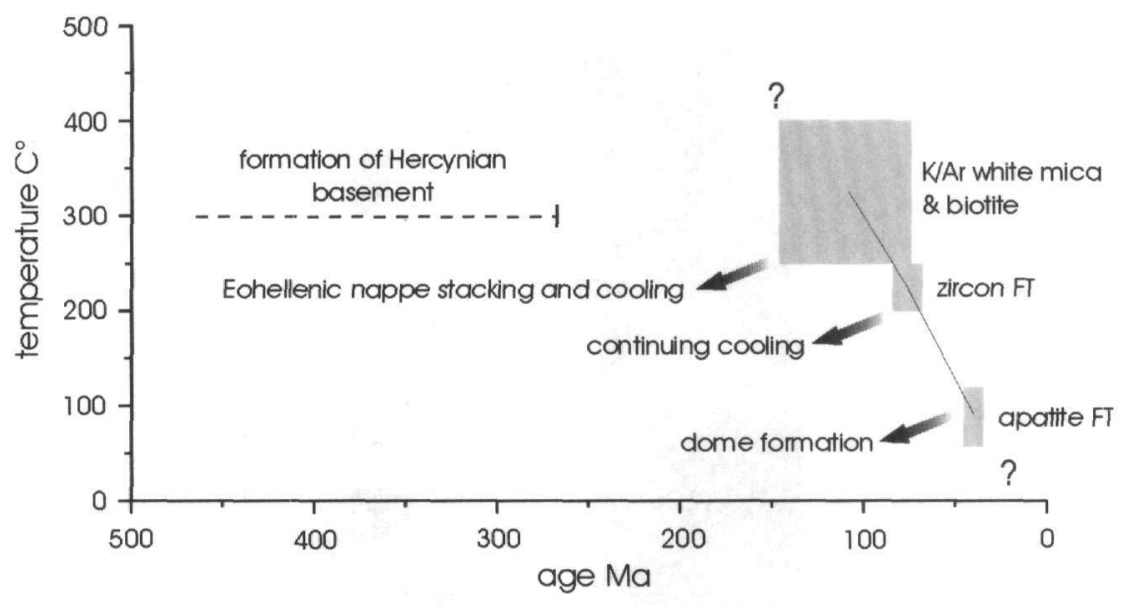

[Fig. 4: Preliminary cooling path of the Central Pelagonian Zone]

\section{4.) THERMOCHRONOLOGICAL DATA}

Geological processes in the ductile regime can be dated by the $\mathrm{K} / \mathrm{Ar}$ method according to the blocking temperatures of the isotopic system for biotite $\left(300^{\circ} \mathrm{C} \pm 50^{\circ} \mathrm{C}\right)$ and white mica $\left(350^{\circ} \mathrm{C} \pm 50^{\circ} \mathrm{C}\right)(\mathrm{PURDY} \&$ $\mathrm{J} \Delta \mathrm{GER}, 1976)$. The closure temperatures of zircon $\left(225^{\circ} \mathrm{C} \pm 25^{\circ} \mathrm{C}\right)$ and apatite $\left(100^{\circ} \mathrm{C} \pm 20^{\circ} \mathrm{C}\right)$ are used to date processes within the brittle, low temperature regime.

\section{1) $\mathrm{K} /$ Ar data}

More than 30 samples from the Central Pelagonian, West Pelagonian and the Vardar Zone (Fig. 3) have been dated by the K/Ar technique. More than 40 biotite and white mica mineral concentrates have been separated by crushing, sieving and density and magnetic separation.

Five groups of mica ages could be differentiated:

(I) The first group comprises ages from biotite and white mica derived from unfoliated granitoids and amphibolites of the Central Pelagonian Zone. They range from $447 \pm 17$ Ma to $267 \pm 10 \mathrm{Ma}$ (Fig. 3) and show that relics of a Hercynian basement are present.

(IIa) Eohellenic ages between $148 \pm 6 \mathrm{Ma}$ and $111 \pm 4 \mathrm{Ma}$ of the second group representing Late Jurassic to Early Cretaceous nappe stacking associated with the development of the dominating fabrics and structures in the rocks of the Central Pelagonian Zone. All micas of this group have been separated from strongly foliated paragneisses, orthogneisses (foliated granites), micaschists, cipollinos and blueschists.

(IIb) Three K/Ar ages between 102 4 Ma and 86 3 Ma derived from micaschists and gneisses from the southern part (Kaimacalan), overlain by mesocoic cover rocks and micaschists of the Vardar Zone (Fig. 3).

(III) Tertiary white mica ages around 64 Ma were obtained from rocks of the Mesocoic sequence (Fig. 3) from the SE part of the study area.

(IV) Westward movement along mylonitic shear zones in the western part of the study area (near Brod and Florina (Fig. 3)) is documented by Upper Eocene to Lower Oligocene K/Ar white mica fabric ages ( $40 \pm 2$ $\mathrm{Ma}$ and $36 \pm 1 \mathrm{Ma})$.

\section{2) Preliminary zircon and apatite fission track data}

Until now 4 zircon and 5 apatite samples have been dated using the external detector method and the zeta calibration approach. 
Zircons from the central part of the Central Pelagonian Zone yield ages between $84 \pm 3 \mathrm{Ma}$ and $68 \pm 4 \mathrm{Ma}$ (Fig. 3). These ages indicate cooling after the Eohellenic tectonometamorphic cycle and lack of Cenocoic reseting.

The apatite fission track ages are systematically younger than the zircon ages and range around $30 \mathrm{Ma}$ in the central part of the CPZ. An age of 45 Ma was obtained near its eastern margin (Fig. 3).

\section{5.) CONCLUSIONS}

According to our ongoing investigations the following cooling path (Fig. 4) of the Eohellenic orogeny can be drawn from the data presented above. Further investigations are in progress and will be presented later. We suggest that the divergent displacements along shear zones are related to the Eocene-Oligocene formation of a metamorphic dome, which is responsible for the present structure of the Pelagonian Zone in the study area.

\section{6.) REFERENCES}

ARSOVSKI, M.; DUMURDZANOV, N.; HRISTOV, S.; IVANOV, T.; IVANOVA, V.; PETKOVSKI, P. \& STOJANOV, R. (1977): Correlation of the Pre-Cambrian complexes of the Pelagonian Massif, Vardar Zone and Serbo-Macedonian massif. - Proceedings of the Colloquium on the Geology of the Aegean Region, 6/2: 549-557.

AUBOUIN, J. (1973): Paleotectonique, tectonique, tarditectonique et neotectonique en Mediterranee moyenne; a la recherche d'un guide pour la comparaison des donnees de la geophysique et de la geologie. - Comptes Rendus Hebdomadaires des Seances de 1'Academie des Sciences, Serie D: Sciences Naturelles. 276/4: $457-$ 460. 1973.

DELEON, G. (1966): translated title „Isotopic age of granitic rocks pf Pelagonia and western Macedonia. - Ref. VI. Colloqium of Jugoslavien Geologists, Ohrid.

DUMURDZANOV, N. (1985): Petrogenic characteristics of the high metamorphic and magmatic rocks of the central and western part of Selecka Mountain, SR Macedonia,.- Yugoslavia. - Geologica Macedonica, 2: 173220, Stip.

PURDY, J.W \& JÄGER, E. (1976): K/Ar ages on rock forming minerals from the Central Alps. - Mem. Inst. Geol. Min. Univ. Padova, 30: 1-31.

JANCEV, S (1977): The Geological and petrological composition of the "Mixed Series" in the Pre-Cambrian complex of the Pelagonian Massif at the upper Babuna River, Macedonia. - Proceedings of the Colloquium on the Geology of the Aegean Region, 6/1: 261-267.

KOSSMAT, F. (1924): Die Kriegsschauplätze 1914-1918 geologisch dargestellt: Geologie der zentralen Balkanhalbinsel. - Brontraeger Verlag, 198 S., Berlin.

LIPS, A.L.W.; WHITE, S.H. \& WIJBRANS, J.R. (1998): ${ }^{40} \mathrm{Ar} /{ }^{39} \mathrm{Ar}$ laserprobe direct dating of discrete deformational events: a continious record of early Alpine tectonics in the Pelagonian Zone, NW Aegean area, Grecce. Tectonophys., 298: 133-153.

LIPS, A.L.W.; WHITE, S.H. \& WIJBRANS, J.R. (1999): New insights from ${ }^{49} \mathrm{Ar} /{ }^{39} \mathrm{Ar}$ laserprobe dating of white mica fabrics from the Pelion Massif, Pelagonian Zone, Internal Hellenides, Greece: implications for the timing of metamorphic episodes and tectonic events in the Aegean region. GSA Spec. Pub., 156: 457-474.

MEDWENITSCH, W. (1956): Zur Geologie Vardarisch-Makedoniens (Jugoslawien), zum Problem der Pelagoniden. - S. Ber. Österr. Ak. Wsch, Math-Naturwsch. Kl, Abt. I, 165/1-10: 397-473, Wien.

PAPANIKOLAOU, D.J.; SASSI, F.P. \& SKARPELIS, N. (1982): Outlines of pre-Alpine metamorphisms in Greece. - Ann. Geol. des Pays Hellen., 31: 16-32.

PAPANIKOLAOU, D.J. \& STOJANOV, R. (1983): Geological correlations between the Creek and Yugoslav parts of the Pelagonian metamorphic belt. - In:SASSI \& SZEDERKENYI (eds.), IGCP Proj. 5 - Newsletter, 5: 146-152.

SCHERMER, E.R.; LUX, D.R. \& BURCHFIEL, B.C. (1990):Temperature-Time History of Subducted Continental Crust, Mt. Olympus Region, Greece. - Tectonics, 9/5: 1165-1195.

WALCOTT, C.R. (1998): The Alpine evolution of Thessaly (NW Greece) and late Tertiary Aegean kinematics. Geologica Ultraiectina,162, 176 S., Utrecht. 